\title{
Treatment of Municipal Landfill Leachate by Oxidants
}

\author{
Shabiimam M. A. ${ }^{1}$, Anil Kumar Dikshit ${ }^{1,2,3, *}$ \\ ${ }^{1}$ Centre for Environmental Science and Engineering, IIT Bombay, Mumbai, 400076, India \\ ${ }^{2}$ School of Civil Engineering, Survey and Construction, University of KwaZulu-Natal, Durban, 4041, South Africa \\ ${ }^{3}$ School of Civil and Environmental Engineering, Nanyang Technological University, 639798, Singapore
}

\begin{abstract}
Landfilling is the one of the least expensive method for disposal of municipal solid waste. Hence, about $90 \%$ of MSW is disposed in open dumps and landfills unscientifically, creating problems to public health and the environment. The leachate generated from the municipal landfill contains organic and inorganic pollutants and several heavy metals, which makes it unsuitable for discharge in natural bodies without any prior treatment. In this study, matured landfill leachate was treated by various oxidation and combination of advanced oxidation process using hydrogen peroxide, sodium persulfate, Fenton's oxidation and ultrasonication-hydrogen peroxide. Fenton's process exhibited the best COD, TOC and color removals( $74 \%$ COD, $76 \%$ TOC and $80 \%$ color respectively) while hydrogen peroxide and sodium persulfate alone showed much lesser TOC reduction(35\% and $39 \%$ respectively).
\end{abstract}

Keywords Landfill Leachate, Fenton Process, Advanced Oxidation Process, Sodium Persulfate, Ultrasonication

\section{Introduction}

Municipal solid waste (MSW) is generated from the waste materials discarded from domestic, commercial, institutional, market and other sources. Food waste, paper, plastic, newspaper, rubber, leather, tin cans, scrap ferrous and nonferrous metals are normal component of MSW. However it might contain hazardous substances like paints, mercury, pharmaceuticals, batteries, and many other items. Municipal landfill is considered to be most common and least expensive method of disposing urban wastes. It is reported that about $90 \%$ of MSW is disposed in open dumps and landfills unscientifically, creating problems to public health and the environment[1]. If landfills are not properly managed, these can give uncontrolled gaseous and liquid emissions. Liquid emission is termed as 'leachate' and it may contain several organic and inorganic compounds and heavy metals. It has been observed that the composition of leachate is dependent on the age of the landfill and the characteristics of disposed waste[2]. The proper treatment and safe disposal of the leachate is one of the major environmental challenges worldwide especially in developing countries like India.

\subsection{Chemical Oxidation}

Chemical oxidation method is used for treatment of leachate containing refractory compounds. In many cases, oxidation was used for the treatment of matured leachate, still having high amount of recalcitrant chemicals[3]. In past

* Corresponding author:

dikshit@iitb.ac.in (Anil Kumar Dikshit)

Published online at http://journal.sapub.org/ajee

Copyright (C) 2012 Scientific \& Academic Publishing. All Rights Reserved few decades, Advanced oxidation process(AOP) is used for the wastewater treatment. It helps to remove the color and organic load from leachate[4,5]. The main attraction is that most of the advanced oxidation processes do not generate sludge[6]. Common AOP processes are based on oxidizing agents like $\mathrm{O}_{3}, \mathrm{H}_{2} \mathrm{O}_{2}$ and combination of $\mathrm{O}_{3}$ and $\mathrm{H}_{2} \mathrm{O}_{2}$. Irradiation techniques are also used to treat the effluent using ultrasonication, microwave, ultraviolet or combination of oxidizing agent with $\mathrm{O}_{3}$. Rivas et al.(2003) investigated the treatment of leachate by ozonation. In $1 \mathrm{~h}$ duration, $30 \%$ COD removal was observed whereas after $120 \mathrm{~h}, 90 \%$ of COD removal was noticed[7]. The oxidation potential of hydroxyl radicals $(2.8 \mathrm{~V})$ is higher than that of ozone $(2.07 \mathrm{~V})$. In addition, $\mathrm{Fe}^{2+}$ and $\mathrm{Fe}^{3+}$ are also known coagulants, which give this process dual advantage of oxidation and coagulation. Yokoyama et al.(2009)[6] investigated the leachate treatment by AOP at initial COD of $5400 \mathrm{mg} / \mathrm{L}$ and Fenton oxidizing agent of $\mathrm{Fe}^{2+}$ (at $720 \mathrm{mg} / \mathrm{L}$ ) was used. $80 \%$ of COD removal was achieved at $\mathrm{pH} 4$ from this process[6]. Other significant advantages of this process over other advanced oxidation processes are non-toxic nature and abundant availability of iron compounds and ease to handle hydrogen peroxide[8]. Lopez et al. (2004) investigated municipal landfill leachate treatment using Fenton process. At optimum $\mathrm{H}_{2} \mathrm{O}_{2}$ dose of $10000 \mathrm{mg} / \mathrm{L}$ and $\mathrm{Fe}^{2+}$ dose of $830 \mathrm{mg} / \mathrm{L}, 60 \%$ COD removal was acheived[9].

Table 1 shows the performance of Fenton process for treatment of leachate reported in literature.

\section{Materials and Methods}

\subsection{Wastewater}

Landfill leachate was collected from Municipal dumping 
yard at Deonar in Mumbai, India and was brought to Environmental Laboratory, IIT Bombay, India. The leachate was stored at $4^{\circ} \mathrm{C}$ in cold room till experimentation. The characterisation of leachate was done as per standard methods[14].

\subsection{Oxidants}

Common oxidizing agents viz. hydrogen peroxide, sodium persulfate, and Fenton's reagent were tested for their suitability for COD, TOC and color removal from the leachate. Hydrogen peroxide solution (30\%) and ferrous sufate were procured from Merck India limited, Mumbai; while sodium persulfate was provided by Moly Chem Limited, Mumbai.

\subsection{Analytical Methods}

COD was measured by closed reflux method using $\mathrm{HACH}$ COD Digester (DRB 200, USA) as given in Standard Methods[14]. Samples were suitably diluted with ultra pure water. Shuimadzu Total Organic Carbon Analyzer (TOC$\mathrm{VCSH}$, Japan) was used for TOC determination from $4 \mathrm{ppb}$ to $25000 \mathrm{ppm}$. $\mathrm{pH}$ of the leachate was measured using digital Thermo Scientific pH Meter(Orion 3 Star, Singapore). Intensity of color was measured in terms of absorbance at 356 $\mathrm{nm}$, which is the characteristic wavelength of brown color. Since apparent color is a significant function of $\mathrm{pH}$, samples were diluted in $1 \mathrm{M}$ phosphate buffer to maintain $\mathrm{pH}$ of 7 . Samples were centrifuged at $10000 \mathrm{rpm}$ for 10 minutes prior to absorbance determination for eliminating hindrance due to suspended particulates in the sample. After that, the supernatant was diluted 10 times and the absorbance was measured at $356 \mathrm{~nm}$ using Thermo Spectronic Visible Spectrophotometer (Helios Epsilon, USA). Reduction in color was estimated in terms of reduction in absorbance with reference to that of the control (original leachate). Heavy metals present in untreated and treated leachate were determined with the help of Jobin Yvon Horiba Inductively Coupled Plasma Spectrophotometer (ULTIMA 2000, France)

\subsection{Hydrogen Peroxide}

The batch studies were conducted on $200 \mathrm{~mL}$ of leachate samples in $500 \mathrm{~mL}$ beakers using jar test apparatus at 250 rpm for $1 \mathrm{~h}$. $\mathrm{pH}$ was varied from 2 to 4.5 by adding $\mathrm{HCl}$ to find optimum $\mathrm{pH}$. At optimum $\mathrm{pH}$, dose of hydrogen per- oxide was varied from 9 to $21 \mathrm{~mL} / \mathrm{L}$ to determine optimum dose. Samples were drawn after 20 minutes and assessed for TOC and color.

\subsection{Sodium Persulfate}

Now, sodium persulfate was used as oxidant and experiments were done same as above. Here dose used varied from 9 to $24 \mathrm{~g} / \mathrm{L}$.

\subsection{Fenton's Oxidation}

For assessing efficacy of Fenton's oxidation towards COD reduction, first optimum $\mathrm{pH}$ was found by performing jar test at $250 \mathrm{rpm}$ with constant dose of $\mathrm{H}_{2} \mathrm{O}_{2}(10 \mathrm{~mL} / \mathrm{L})$ and $\mathrm{FeSO}_{4}$ $(3 \mathrm{~g} / \mathrm{L})$ and varying $\mathrm{pH}$ from 2 to 4.5 . Taking $\mathrm{pH}$ constant at optimum and dose of $\mathrm{FeSO}_{4}$ same as above, second run of jar test was done from 6 to $21 \mathrm{~mL} / \mathrm{L}$ to optimize the dose of $\mathrm{H}_{2} \mathrm{O}_{2}$. In the third run, the dose of $\mathrm{FeSO}_{4}$ was varied from 1 to $6 \mathrm{~g} / \mathrm{L}$ to optimise it taking optimum dose of $\mathrm{H}_{2} \mathrm{O}_{2}$ at optimum $\mathrm{pH}$. A pinch of manganese dioxide was added to samples for remove effect of residual $\mathrm{H}_{2} \mathrm{O}_{2}$ before measuring its $\mathrm{COD}$. TOC and colour were also monitored.

\subsection{Ultrasonication-Hydrogen Peroxide}

Studies were also carried out to find the effect of combined treatment with ultrasound and hydrogen peroxide. 200 $\mathrm{mL}$ of leachate sample was treated using $20 \mathrm{~Hz}$ frequency ultrasonicator with various concentration of hydrogen peroxide to find the optimum $\mathrm{pH}$ and dose.

\section{Result and Discussion}

\subsection{Characteristics of Landfill Leachate}

Initial $\mathrm{pH}$ was of landfill leachate was 7.9 , turbidity was 317 NTU while COD was $2451 \mathrm{mg} / \mathrm{L}$ and BOD was 202 $\mathrm{mg} / \mathrm{L}$ and the $\mathrm{BOD} / \mathrm{COD}$ was 0.09 . From the $\mathrm{pH}$ and $\mathrm{BOD} / \mathrm{COD}$ ratio, it can be concluded that the leachate had already achieved matured phase and it was not suitable for biological treatment[15].

Table 1 shows the amount of heavy metals present in the leachate. In mature phase, most of the heavy metals concentrations were low because of the dissolution[12].

Table 1. Performance of Fenton Process

\begin{tabular}{|c|c|c|c|c|c|c|}
\hline \multicolumn{2}{|c|}{ Feed stream characteristics } & \multirow{2}{*}{$\mathrm{H}_{2} \mathrm{O}_{2}(\mathrm{~g} / \mathrm{L})$} & \multirow{2}{*}{$\left.\mathrm{Fe}^{2+(} \mathrm{mg} / \mathrm{L}\right)$} & \multirow{2}{*}{$\begin{array}{l}\mathrm{BOD} / \mathrm{COD} \text { ratio } \\
\text { of treated effluent }\end{array}$} & \multirow{2}{*}{ Result obtained } & \multirow{2}{*}{ References } \\
\hline $\mathrm{COD}(\mathrm{mg} / \mathrm{L})$ & $\mathrm{pH}$ & & & & & \\
\hline 1500 & 4- 6 & 0.2 & 300 & - & $70 \%$ of COD removed & [10] \\
\hline 4113- 9257 & 8.1 & 3.5 & 437.5 & 0.71 & $76 \%$ of $\mathrm{COD}$ and $10 \%$ of $\mathrm{NH}_{4}-\mathrm{N}$ removed & [11] \\
\hline 38200 & 7.3 & 5 & 200 & 0.64 & $55.9 \%$ of COD and $89.4 \%$ color removed & [12] \\
\hline 743 & 3.5 & $\mathrm{H}_{2} \mathrm{O}_{2} / \mathrm{Fe}^{2+}=3$ & $4 \mathrm{mmol} / \mathrm{L}$ & 0.15 & $46 \%$ COD removed & [3] \\
\hline $932-1325$ & 7 & 1.35 & $\mathrm{Fe}^{2+} / \mathrm{H}_{2} \mathrm{O}_{2}=0.2$ & - & $61 \%$ COD removed & [13] \\
\hline
\end{tabular}

Table 2. Heavy Metals Concentration of Landfill Leachate

\begin{tabular}{|c|c|c|c|c|c|c|c|}
\hline Parameter & As & $\mathrm{Ba}$ & $\mathrm{Bi}$ & $\mathrm{Co}$ & $\mathrm{Cr}$ & $\mathrm{Hg}$ & $\mathrm{Li}$ \\
\hline Value $(\mathrm{mg} / \mathrm{L})$ & 0.09 & 0.51 & 0.15 & 0.11 & 0.16 & 0.02 & 0.08 \\
\hline
\end{tabular}




\subsection{Hydrogen Peroxide}

Hydrogen peroxide, most popular oxidising agent being used in various industrial applications, was tried as oxidant for leachate.

\subsubsection{Effect of $\mathrm{pH}$ on the Oxidation of Leachate using Hydrogen Peroxide}

At first step, $12 \mathrm{~mL} / \mathrm{L}$ hydrogen peroxide was mixed per $200 \mathrm{~mL}$ of landfill leachate and its $\mathrm{pH}$ was adjusted from 2 to 4.5 with the help of $\mathrm{HCl}$. Figure 1a shows the variation in the TOC and color removal of the sample with respect to its $\mathrm{pH}$. Optimum $\mathrm{pH}$ was found as 2 .

\subsubsection{Effect of Hydrogen Peroxide Dose on the Oxidation of Leachate}

At optimal $\mathrm{pH}$, varying doses of hydrogen peroxide were added to landfill leachate and the COD and color removal efficiency were determined. Color removal increased with increase in the dose of hydrogen peroxide but at higher doses beyond $15 \mathrm{~mL} / \mathrm{L}$, there was little increase in the color removal (Figure 1b). In jars having high doses, there was so excessive foaming that they could be operated with great difficulty. Keeping operational ease and economics of treatment in mind, the dose of $18 \mathrm{~mL} / \mathrm{L}$ was suggested which gave a 39\% reduction in TOC and 34\% reduction in color.

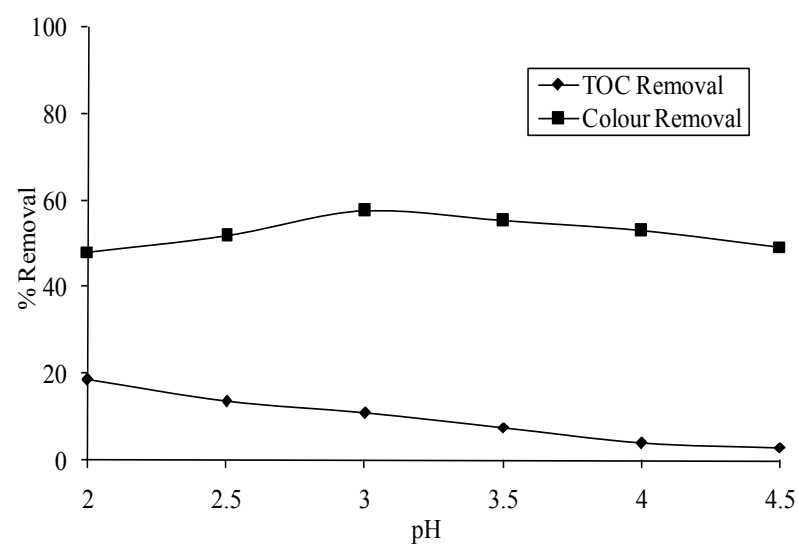

(a)

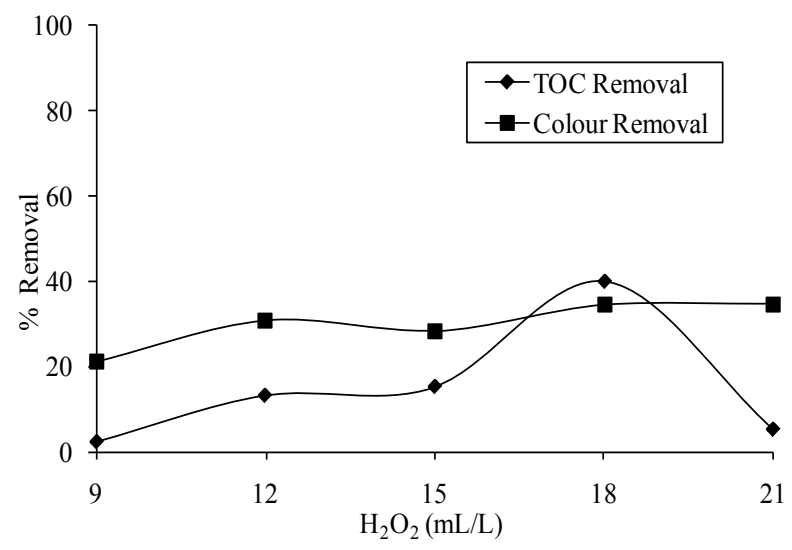

(b)

Figure 1. TOC and Color Removals by Oxidation of $\mathrm{H}_{2} \mathrm{O}_{2}$ (a) at Various $\mathrm{pH}$ and(b) at Various Doses of Hydrogen Peroxide

\subsection{Sodium Persulfate}

Sodium Persulfate is another highly reactive oxidant. It was also tried as oxidant for treatment of landfill leachate.

\subsubsection{Effect of $\mathrm{pH}$ on the Oxidation of Leachate using Sodium Persulfate}

At first step, $12 \mathrm{~g} / \mathrm{L}$ of Sodium Persulfate was mixed per $200 \mathrm{~mL}$ of landfill leachate and its $\mathrm{pH}$ was adjusted from 2 to 4.5 with the help of $\mathrm{HCl}$. Figure $2 \mathrm{a}$ shows the variation in the color and TOC removal of the treated sample with respect to its $\mathrm{pH}$. Optimum $\mathrm{pH}$ was found as 2.

\subsubsection{Effect of Sodium Persulfate Dose on the Oxidation of Leachate}

At optimal $\mathrm{pH}$, varying doses of sodium persulfate were added to landfill leachate and the TOC and color removal efficiency were determined. Color removal increased with increase in the dose of hydrogen peroxide but at higher doses beyond $18 \mathrm{~g} / \mathrm{L}$, there was little decrease in the color removal (Figure $2 \mathrm{~b}$ ). The dose of $18 \mathrm{~g} / \mathrm{L}$ was suggested which gave an optimum removal of $35 \%$ in TOC and $79 \%$ in color.

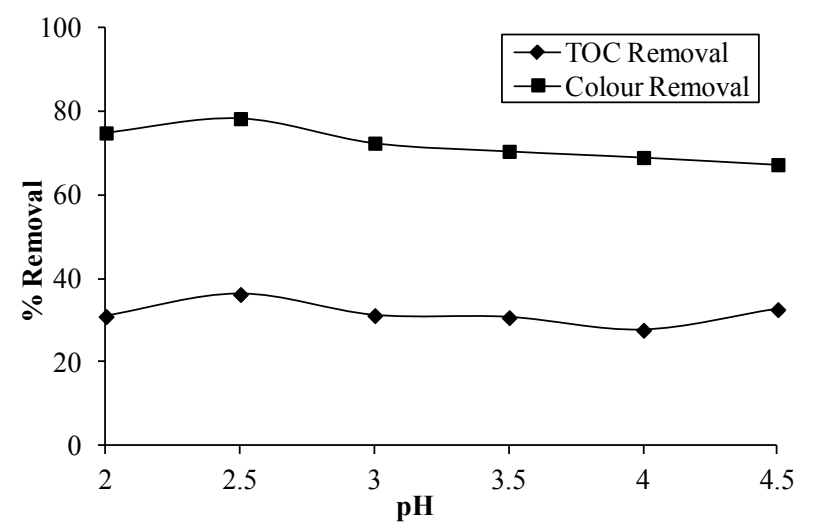

(a)

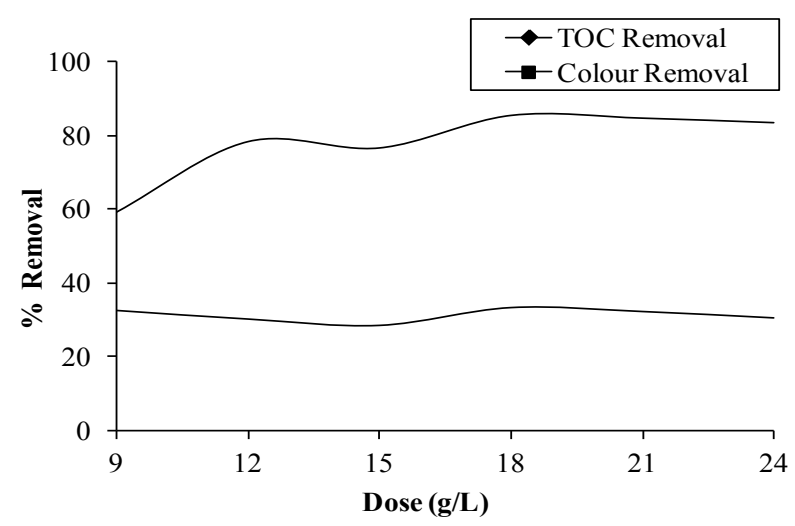

(b)

Figure 2. TOC and Color Removals by Oxidation using Sodium Persulfate(a) at Various $\mathrm{pH}(\mathrm{b})$ at Various Doses of Sodium Persulfate

\subsection{Fenton's Oxidation}

Fenton's oxidation is very promising option for oxidation of toxic and refractory organic matter. Fenton's reaction at acidic $\mathrm{pH}$ produces ferric ions and hydroxyl radicals. The 
formation of hydroxyl radical and oxidation of $\mathrm{Fe}^{2+}$ to $\mathrm{Fe}^{3+}$ state is responsible for its high oxidation potential.

\subsubsection{Effect of $\mathrm{pH}$ on the Fenton's Oxidation of Leachate}

Many of the literature revealed Fenton's oxidation process takes place in the acidic $\mathrm{pH}$ range, and hence the test for optimum $\mathrm{pH}$ was considered in this range. In six jars with winter leachate samples, $\mathrm{pH}$ was adjusted from 2 to 4.5 with increment of 0.5 with the help of $\mathrm{HCl}$. After that, constant dose of $10 \mathrm{~mL} / \mathrm{L}$ hydrogen peroxide and $3 \mathrm{~g}$ ferrous sulfate was added per litre of leachate. Jars were subjected to standard test as described in methodology for Fenton's oxidation process. COD, TOC and color removals were noted and based on that, the optimum $\mathrm{pH}$ of 4.5 was selected (Figure 3a).

\subsubsection{Effect of Hydrogen Peroxide Dose on Fenton's Oxi- dation of Leachate}

At optimum $\mathrm{pH}$ of 4.5 , the exercise was again repeated to determine optimum dose of hydrogen peroxide. In this step, $\mathrm{pH}$ was kept constant as 4.5 along with dose of ferrous sulfate $(3 \mathrm{~g} / \mathrm{L})$. Dose of hydrogen peroxide was varied from 6 to $21 \mathrm{~mL} / \mathrm{L}$.

Figure $3 \mathrm{~b}$ shows the pattern of COD, TOC and color removal. Optimum dose of hydrogen peroxide was found as 12 $\mathrm{mL} / \mathrm{L}$. At higher doses, there was no further increase in color removal.

\subsubsection{Effect of Ferrous Sulphate Dose on Fenton's Oxidation of Leachate}

In the study, the $\mathrm{pH}$ as well as dose of hydrogen peroxide were kept as constant (i.e. 4.5 and $12 \mathrm{~mL} / \mathrm{L}$ ) and the dose of ferrous sulfate was varied. As is clear from the results shown in Figure 3c, the best combination for Fenton's oxidation was found as $\mathrm{pH} 4.5,12 \mathrm{~mL} / \mathrm{L} \mathrm{H}_{2} \mathrm{O}_{2}$ and $3 \mathrm{~g} / \mathrm{L}$ ferrous sulphate, which gave maximum reduction of $74 \%$ in COD, $76 \%$ in TOC and $80 \%$ in color of leachate.

\subsection{Ultrasonication- $\mathrm{H}_{2} \mathrm{O}_{2}$}

Ultrasonication and Hydrogen peroxide, another combination of advanced oxidation used in various industrial applications, was also tried as oxidant for leachate.

\subsubsection{Effect of $\mathrm{pH}$ on Ultrasonication of Landfill Leachate}

At first step, the beaker contains $200 \mathrm{ml}$ of sample was kept in a sonicator for $1 \mathrm{~h}, 12 \mathrm{~mL} / \mathrm{L}$ Hydrogen peroxide was mixed per $200 \mathrm{~mL}$ of landfill leachate and its $\mathrm{pH}$ was adjusted from 2 to 4.5 with the help of $\mathrm{HCl}$. Figure 4a shows the variation in the organic pollutant removal of the sample with respect to its $\mathrm{pH}$. Optimum $\mathrm{pH}$ was found as 2 .

\subsubsection{Effect of Hydrogen Peroxide Dose on Ultrasonication of Landfill Leachate}

At optimal $\mathrm{pH}$, varying doses of hydrogen peroxide were added to landfill leachate and the TOC and color removal efficiency were determined. Color removal decreased with increase in the dose of hydrogen peroxide but at dose of 12 $\mathrm{ml} / \mathrm{L}$ maximum TOC and color removal was achieved (Figure $4 \mathrm{~b}$ ). A high dose of $\mathrm{H}_{2} \mathrm{O}_{2}$ has given excessive foaming that they could be operated with great difficulty. Keeping operational ease and economics of treatment in mind, the dose of $12 \mathrm{~mL} / \mathrm{L}$ was finalized with a $36 \%$ reduction in TOC and $79 \%$ reduction in color.

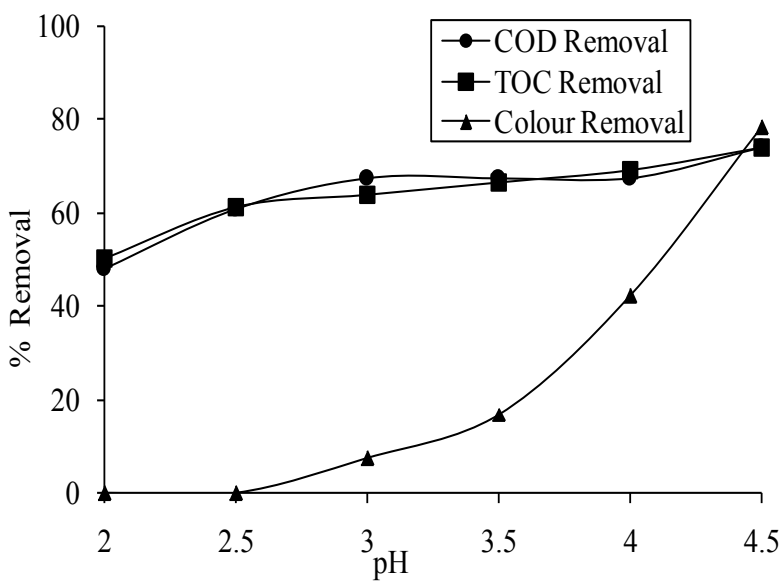

(a)

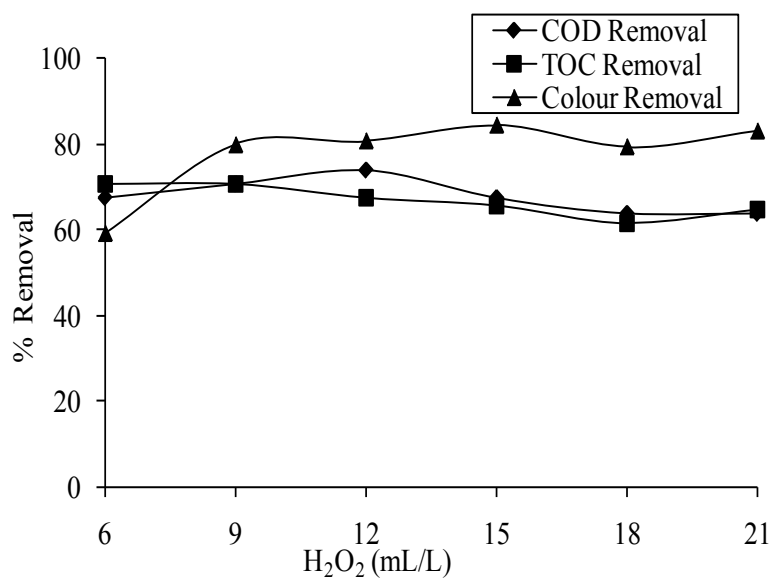

(b)

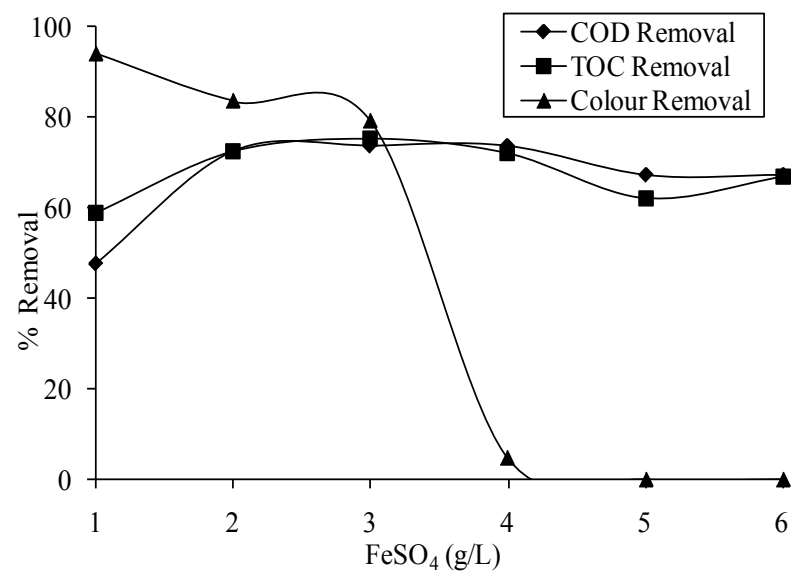

(c)

Figure 3. COD, TOC and Color Removals by Fenton's Oxidation(a) at Various $\mathrm{pH}(\mathrm{b})$ at Various Doses of $\mathrm{H}_{2} \mathrm{O}_{2}$ (c) at Various Doses of $\mathrm{FeSO}_{4}$. 


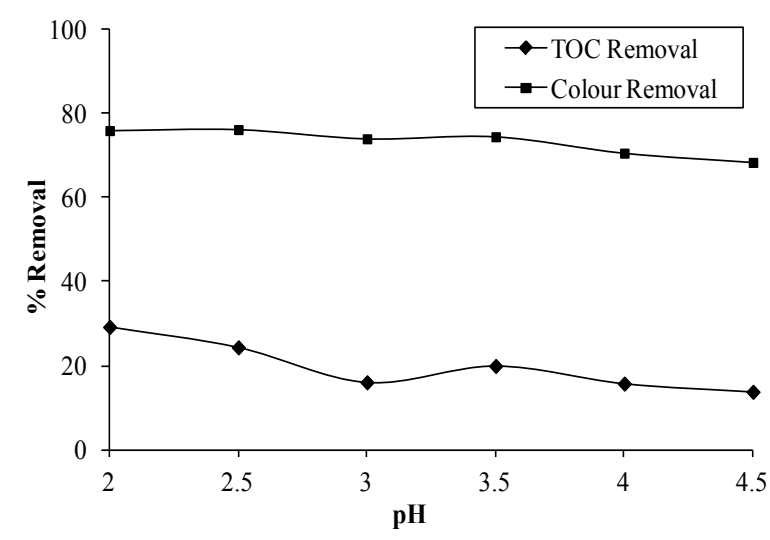

(a)

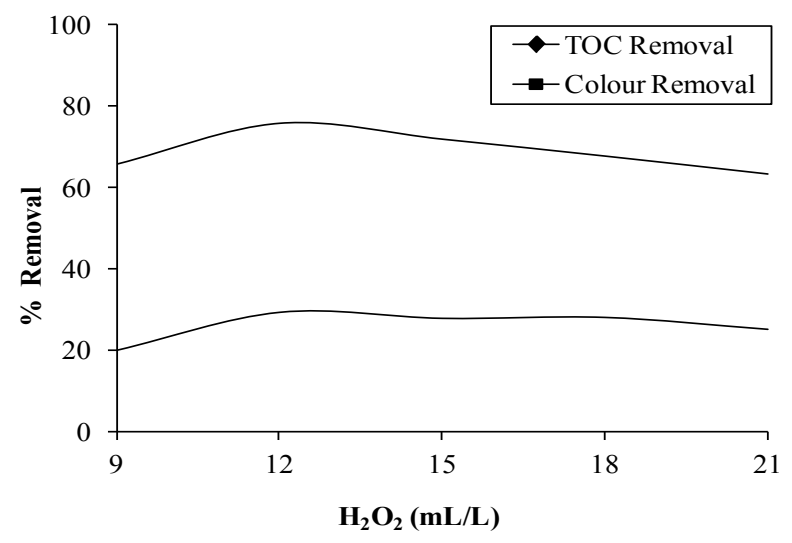

(b)

Figure 4. TOC and Color Removals by Ultrasonication Combined with Hydrogen Peroxide(a) at Various pH(b) at Various Doses of $\mathrm{H}_{2} \mathrm{O}_{2}$

\section{Conclusions}

Hydrogen peroxide alone could hardly remove $39 \%$ TOC and $34 \%$ color at optimum $\mathrm{pH}$ of 2 with optimum dose as 18 $\mathrm{mL} / \mathrm{L}$. Combination of ultrasonic destruction and hydrogen peroxide was also found to be not effective, it could remove $36 \%$ TOC and $79 \%$ color at optimum $\mathrm{pH}$ of 2 and optimum dose of $12 \mathrm{ml} / \mathrm{L}$. TOC and color removal by oxidation of sodium persulfate also did not achieved better removal $(35 \%$ TOC and $79 \%$ color). From the experimental results, the oxidant alone could remove the TOC in the range of $35-39 \%$.

Fenton's oxidation gave the best results with total removal of $74 \% \mathrm{COD}, 76 \%$ TOC and $80 \%$ color at optimum initial $\mathrm{pH}$ of 4.5 with optimum doses $12 \mathrm{~mL} / \mathrm{L}$ hydrogen peroxide and $3 \mathrm{~g} / \mathrm{L}$ of ferrous sulfate.

\section{ACKNOWLEDGEMENTS}

The authors thank the management and staff of the Solid Waste Division, Municipal Corporation of Greater Mumbai, Mumbai, India for providing the landfill leachate used in the research work.

\section{REFERENCES}

[1] Sharholy, M., Ahmad, K., Mahmood, G., Trivedi, R. C., 2008, Municipal solid waste management in Indian cities - A review., Waste Management, 289(2), 459-67

[2] Baig, S., Coulomb, I., Courant, P., Liechti, P., 1999, Treatment of Landfill Leachates: Lapeyrouse and Satrod Case Studies, Ozone: Science \& Engineering, 21(1), 1-22

[3] Cortez, S., Teixeira, P., Oliveira, R., and Mota, M., 2011, Evaluation of Fenton and ozone-based advanced oxidation processes as mature landfill leachate pre-treatments., Journal of Environmental Management, 92(3), 749-55

[4] Wu, Y., Zhou, S., Qin, F., Peng, H., Lai, Y., Lin, Y., 2010, Removal of humic substances from landfill leachate by Fenton oxidation and coagulation, Process Safety and Environmental Protection, 88(4), 276-284

[5] Renou, S., Givaudan, J. G., Poulain, S., Dirassouyan, F., Moulin, P., 2008, Landfill leachate treatment: Review and opportunity., Journal of Hazardous Materials, 150(3), 468-93

[6] Yokoyama, L., Araujo, F. V. F., Campos, J. C., Freire, L. F. A., Teixiera, I. A. C., 2009, Landfill Leachate Treatment with Advanced Oxidation Process, Proceedings Sardinia, Twelfth International Waste Management and Landfill Symposium, S. Margherita di Pula, Cagliari, Italy

[7] Rivas, F. J., Beltrán, F., Carvalho, F., Acedo, B., Gimeno, O., 2004, Stabilized leachates: sequential coagulation- flocculation + chemical oxidation process., Journal of Hazardous Materials, 116(1-2), 95-102

[8] Benatti, C. T., Tavares, C. R. G., Guedes, T. A., 2006, Optimization of Fenton's oxidation of chemical laboratory wastewaters using the response surface methodology, Journal of Environmental Management, 80(1), 66-74

[9] Lopez, A., Pagano, M., Volpe, A., Di Pinto, A. C., 2004, Fenton's pre-treatment of mature landfill leachate, Chemosphere, 54, 1005-1010

[10] Wang, P., Lau, I., Fang, H., Zhou, D., 2000, Landfill leachate treatment with combined uasb and fenton coagulation. Journal of Environmental Science and Health, Part A, 35(10), 1981-1988

[11] Barnes, D., Li, X., Chen, J., 2007, Determination of Suitable Determination of suitable pre-treatment method for old-intermediate landfill, Environmental Technology, 28(2), 195-203

[12] Yilmaz, T., Aygün, A., Berktay, A., Nas, B., 2010, Removal of COD and color from young municipal landfill leachate by Fenton process, Environmental Technology, 31(14), 1635-1640

[13] Barbusi, K., and Pieczykolan, B., 2010, COD removal from landfill leachate using Fenton oxidation and coagulation, Architecture Civil Engineering Environment, 3, 93-100

[14] "Standard Methods for the Examination of Water and Wastewater, 2005, 2nd ed., APHA, Washington, DC

[15] Kjeldsen, P., Barlaz, M. A., Rooker, A. P., Baun, A., Ledin, A., Christensen, T. H., 2002, Present and long-term composition of MSW landfill leachate: a review, Critical Reviews in Environmental Science and Technology, 32(4), 297-336 